\title{
DEVELOPMENT AND EVALUATION OF A LYOPHILIZED PRODUCT CONTAINING INSULIN ${ }^{1}$
}

\author{
DESENVOLVIMENTO E AVALIAÇÃO DE \\ PRODUTO LIOFILIZADO CONTENDO INSULINA
}

\section{Thais Seixas Certo ${ }^{2}$, Júnia Graziela Oliveira ${ }^{3}$, Gabriel Silva Marques Borges ${ }^{3}$, Lucas Andrade Ferreira ${ }^{3}$ e José Mario Barichello ${ }^{4}$}

\begin{abstract}
This study aimed at developing and evaluating lyophilized products from F127 (F127) Pluronic solutions containing insulin (INS) and oleic acid (OA) as absorption enhancer. The release of INS from gelatin capsules containing the lyophilized products in different media and at the average size of micelles/ vesicles generated in the release media were the parameters evaluated to characterize the formulations. Results indicated that the release media played an important role in the liberation of INS from capsules containing the lyophilized products. Additionally, small micelles/vesicles were formed in the release media during the INS release, which may be decisive for in vivo INS permeation through the intestine membrane. Taking into consideration the smaller size of micelles/vesicle formed in media containing bile salts, and a slower release of INS in these media, F127 formulations containing unsaturated fatty acids are possible candidates for developing oral formulations of insulin.
\end{abstract}

Keywords: In vitro release, Micelles/vesicle size, Hydrogel.

\section{RESUMO}

Este trabalho teve como objetivo desenvolver e avaliar produtos liofilizados a partir de soluções de Pluronic F127 (F127) contendo insulina (INS) e ácido oleico (OA) como promotor de absorção. A liberação de INS em diferentes meios a partir de cápsulas de gelatina contendo o produto liofilizado e o tamanho médio das micelas/vesículas geradas no meio de liberação foram os parâmetros avaliados para caracterizar as formulações. Os resultados demonstraram que o meio de dissolução influenciou a liberação de INS a partir de cápsulas contendo o produto liofilizado. Adicionalmente, pequenas micelas/vesículas foram formadas nos meios de dissolução contendo sais biliares durante a liberação de INS, fato que pode ser decisivo in vivo para a permeação de INS através da membrana do intestino. Levando em consideração as micelas/vesículas de menor tamanho formadas em meio contendo sais biliares e uma liberação mais lenta de INS nestes meios, formulações de F127 contendo ácidos graxos insaturados são possíveis candidatos ao desenvolvimento de formulações orais de INS.

Palavras-chaves: Liberação in vitro, Tamanho de micelas/vesículas, Hidrogel

\footnotetext{
${ }^{1}$ Pesquisa realizada no Programa de Pós-Graduação em Ciências Farmacêuticas da Universidade Federal de Ouro Preto.

${ }^{2}$ Mestranda do Programa de Pós-Graduação em Ciências Farmacêuticas, Escola de Farmácia, Universidade Federal de Ouro Preto. E-mail: thaiscerto@yahoo.com.br

${ }^{3}$ Acadêmicos do Curso de Farmácia, Escola de Farmácia, Universidade Federal de Ouro Preto. E-mail: juniagrama@, yahoo.com.br; gsmb70@yahoo.com.br; lucasandrad8@hotmail.com

${ }^{4}$ Orientador. Professor Adjunto da Escola de Farmácia, Universidade Federal de Ouro Preto. E-mail: josemariobarichello@, gmail.com
} 


\section{INTRODUCTION}

Noninvasive methods for peptides administration, such as insulin (INS), to the systemic circulation and, thus, to a target cell or organ have received considerable attention from the pharmaceutical industry and the medicine (SILVA et al., 2003). Alternative routes for INS administration have been investigated and includes: pulmonary, oral, transdermal, nasal, ocular and rectal routes (OBACH et al., 1999). However, the subcutaneous administration of INS is still remained as the main route used for treating diabetes type 1 . To date, only the pulmonary route was clinically approved to replace it (SIEKMEIER et al., 2008).

Oral administration of INS would be the most convenient for diabetic patients since the passage of this hormone by the liver could prevent or mitigate systemic hyperinsulinemia and its complications, common in subcutaneous administration (FONTE et al., 2013). The high molecular weight ( $\sim 6 \mathrm{kDa})$ and the low lipophilicity are limiting factors that carry INS to a very low absorption by the mucosal membrane. The proteolytic activity of enzymes in the stomach and small intestine also account for the rapid degradation of INS orally administered (FONTE et al., 2013). Additionally, the INS mucosal administration without the use of absorption promoters produces no appreciable change in INS plasma concentrations. Therefore, besides the protection of the molecule, the use of absorption promoters, such as surfactants, bile acids or unsaturated fatty acids, are required to increase INS bioavailability after oral administration (CHOONARA et al., 2014).

Fatty acids are endogenous compounds present in human skin (LAMPE et al., 1983) and biomembranes (FISCHER, 1989). They are very often used as absorption promoters in drug delivery systems for lungs and intestine (SHARMA et al., 2005). The use of $2 \%$ oleic acid (OA) in a W/O/W emulsion as an absorption enhancer of INS was demonstrated to cause an important hypoglycemic effect with little damage to the rectal mucosa, and no tissue damage to the colon when the formulation was administered rectally (MORISHITA et al., 2000).

Pluronic ${ }^{\circledR}$ F-127 (F127) is a non-ionic surfactant whose aqueous solutions at 20\% or more are micellar liquids at low temperatures, turning into a semi rigid gel by increasing the temperature above $25^{\circ} \mathrm{C}$ (DUMORTIER et al., 2006). We have previously demonstrated that F127 formulations containing unsaturated fatty acids resulted in an important hypoglycemic effect of INS after rectal (BARICHELLO et al., 1999a) and buccal (MORISHITA et al., 2001) administration to normal rats.

In this work, we designed a lyophilized product from F127 solutions containing OA and INS with the perspective to use it in the future development of colon-specific formulations for oral administration of INS. The Lyophilized product was evaluated in vitro in regard to INS release profile in different media and the mean size of the micelles aroused in the different release media tested. 


\section{MATERIAL AND METHODS}

\section{Material}

Pluronic F-127 (F127), D,L- $\alpha$-tocopherol, Oleic acid (OA), bile salts (BS) and trifluoroacetic acid were purchased from Sigma-Aldrich Co. (St. Louis, MO, USA). Potassium dihydrogenphosphate, di-sodium hydrogen phosphate anhydrous, acetonitrile (HPLC grade) and sodium chloride $(\mathrm{NaCl})$ were purchased from Merck (Darmstad, Germany). Hydrochloric acid ( $\mathrm{HCl})$ titrant solution was purchased from Synth (Diadema, SP, Brazil) and sodium hydroxide $(\mathrm{NaOH})$ titrant solution was purchased from Cromoline (Diadema, SP, Brazil). Erythrosine dye was purchased from Vetec (Duque de Caxias, RJ, Brazil). The human insulin (INS) was a kind gift from Novonordisk (Montes Claros, MG, Brazil) and the hard-gelatin capsules Catalent (Sorocaba, SP, Brazil), size 00, were a kind gift from Farmácia Acurácia (Mariana, MG, Brazil).

\section{Preparation of F127 solutions}

The F127 solutions were prepared as previously described (BARICHELLO et al., 1999b). A weighed amount of F127 (12 and 16\%) was slowly added to a phosphate buffer saline solution pH 7.4 (PBS 7.4) in an ice-water bath under gentle mixing by using a magnetic stirrer. The F127 solution was stored in a refrigerator overnight to allow complete dissolution of the polymer. The F127 solution was placed in an ice-water bath and D,L- $\alpha$-tocopherol $(0.06 \%)$ was dispersed under gentle mixing. Then, OA $(2,0 \%)$ was added under vigorous agitation until a milky solution was obtained. INS (1 mg/g of solution) was dissolved in $0.1 \mathrm{M} \mathrm{HCl}$ solution and directly added to the F127 solution. The acid was neutralized with a $0.1 \mathrm{M} \mathrm{NaOH}$ solution.

\section{Freeze-drying process}

The Freeze-drying process was realized as previously described (REY et al., 1999). The F127 solutions were poured into capsules body (00 size) and the capsules body were rapidly frozen for 20 minutes in a $-80^{\circ} \mathrm{C}$ freezer (Forma-86C freezer ULT, Thermo Scientific, Brazil). The weights of capsules body were registered before and after filling. The frozen capsules body containing the formulations were lyophilized at a condition of $-40^{\circ} \mathrm{C}$, under vacuum (pump speed of $10 \mathrm{~m}^{3} / \mathrm{h}$ ), for approximately 20 hours, in a lyophilizer L101 (Liobrás, Brazil). The capsules body containing the lyophilized products were weighted, closed with the capsule cup and stored in a $-20^{\circ} \mathrm{C}$ freezer until use. 


\section{In vitro insulin release study}

The in vitro INS release from capsules containing the lyophilized products was done as follows: one capsule (about $0.8 \mathrm{~g}$ ) was submersed in a flat-bottomed falcon tube containing $5 \mathrm{~mL}$ of a release medium. The release media evaluated were: $0.1 \mathrm{M}$ hydrochloric acid, $\mathrm{pH} 0.8(0.1 \mathrm{M} \mathrm{HCl})$; phosphate buffer saline solution, $\mathrm{pH} 7.4$ (PBS 7.4); 0.1\% bile salt aqueous solution ( $0.1 \% \mathrm{BS}$ ) and; $1.0 \%$ bile salt aqueous solution $(1.0 \% \mathrm{BS})$. The tubes were fixed to a horizontal shaking tray of a water bath. The temperature of the water bath was set to $37^{\circ} \mathrm{C}$ and the horizontal movement set to $75 \mathrm{rpm}$. After two hours, the shaking was stopped and $1 \mathrm{~mL}$ of the release media was collected and filter through a 0,45 $\mu \mathrm{m}$ PTFE filter, $13 \mathrm{~mm} \varnothing$ (Allcrom, São Paulo, Brazil) to quantified the INS released. Each formulation was evaluated in triplicate.

\section{Quantification of insulin}

The quantification of INS was proceeded as previously described (BARICHELLO et al., 1999c) The INS amount in each sample was quantified in an auto sampler Waters HPLC System Alliance 2695 with a Waters 2996 PDA detector. A Phenomenex Luna C18 column (150x4.60 mm) (Allcrom, São Paulo, Brazil), with a $5 \mu \mathrm{m}$ particle diameter and a pore size of $100 \AA$ was used. The mobile phase composed of acetonitrile, $0.1 \%$ trifluoroacetic acid and sodium chloride (31:69:0.58, v/v/w) was eluted at a flow rate of $1.0 \mathrm{ml} / \mathrm{min}$. The injection volume was $100 \mu \mathrm{L}$ and the detection of INS was realized in the wavelength of $214 \mathrm{~nm}$.

\section{Mean micelle/vesicles size in the release media}

Aliquots of the release media were collected at the end of the INS release study to determine the mean micelle/vesicle size in the release media. Those aliquots were properly diluted with ultrapure water and transferred to a quartz cuvette for analysis by dynamic light scattering in a Nanosizer N5 Submicron Particle Size Analyser (Beckman Coulter, USA). The incident scattering angle was set to $90^{\circ}$. The analyses were realized in quadruplicate and the lower diffusion coefficient obtained was discharged. The mean micelle/particle sizes were compared among the dissolution media and between the formulations.

\section{Statistical analysis}

The unpaired Student $t$ test or one-way ANOVA was used. Thereafter, post hoc multiple comparisons of data were analyzed with Tukey-Kramer test. The existence of difference between the amounts of INS released was considered significant when $\mathrm{P}<0.025$, adopting the confidence interval 
of $95 \%$. The release data were expressed as the mean \pm standard deviation. The BioEstat software (Belém, PA, Brazil) was used for statistical analysis (AYRES et al., 2007).

\section{RESULTS AND DISCUSSION}

The in vitro release study permits to evaluate the effect of different formulation compositions on drug release, as well as the effect that the release media exert on formulation performance. The release of INS from capsules containing the lyophilized products was evaluated in $0.1 \mathrm{M} \mathrm{HCl,} \mathrm{PBS} \mathrm{7.4,}$ $0.1 \% \mathrm{BS}$ and $1.0 \% \mathrm{BS}$ media and the results were compared among them.

Figure 1- Percentage of insulin released from capsules containing 12\% and 16\% F127 lyophilized product after two hours in different dissolution media. Legend: significant difference between the INS released amount in the medium compared to: (*) BS 0.1\%; (\#) BS 1.0\%; (\$) 0.1M HCl and (\&) PBS 7.4.
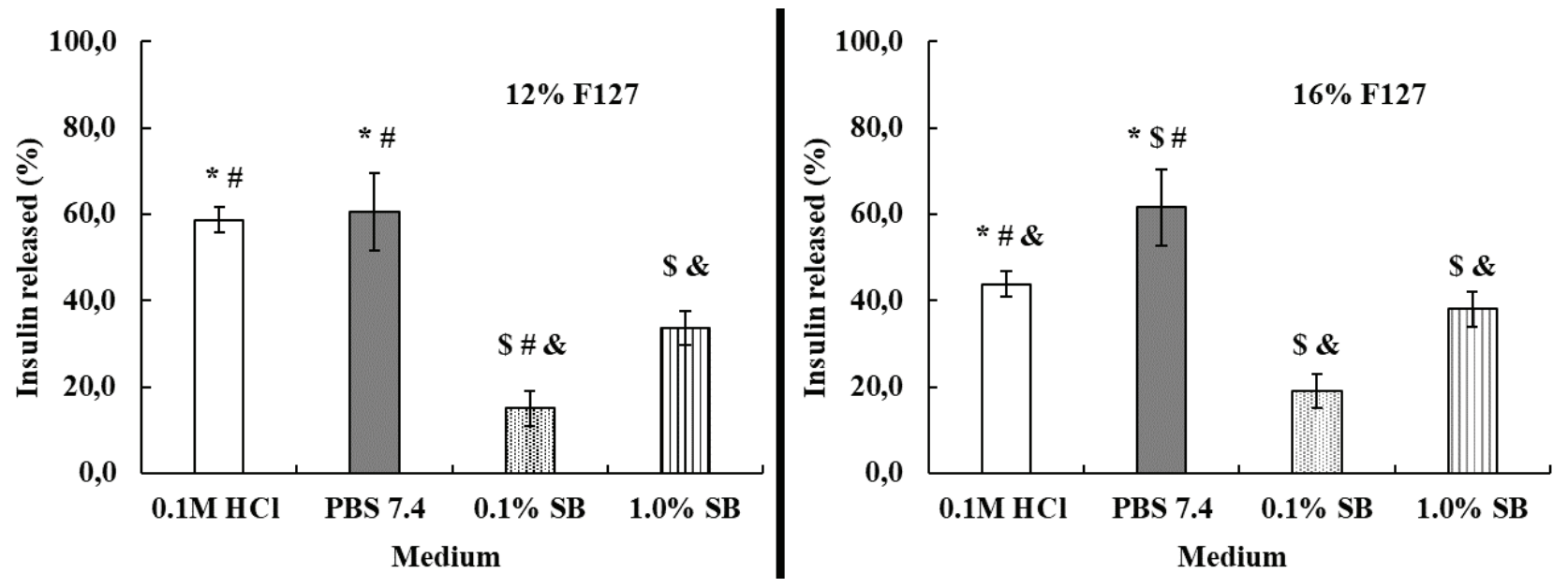

The INS release profile from capsules containing 12\% F127 lyophilized product in different media is shown in Fig. 1. It is observed in Fig. 1 that the release profile of INS from capsules containing $12 \%$ F127 was affected by the dissolution media used. In $0.1 \%$ BS media, the percentage of INS released was the lowest (15.02 $\pm 4.04 \%)$, followed by $1.0 \% \mathrm{BS}(33.69 \pm 3.94 \%), 0.1 \mathrm{M} \mathrm{HCl}(58.62 \pm 2.92 \%)$ and PBS $7.4(60.61 \pm 8.95 \%)$. For capsules containing 12\% F127, the higher percentage of INS released were in $0.1 \mathrm{M} \mathrm{HCl}$ and PBS 7.4, were INS was freely soluble.

The INS release profile from capsules containing 16\% F127 lyophilized product in different media is also shown in Fig. 1. It is observed in Fig. 1 that the release profile of INS from capsules containing 16\% F127 was also affected by the dissolution media used. The crescent order of INS release from capsules containing 16\% F127 lyophilized product was 0.1\% BS (19.05 \pm 1.64\%), 1.0\% BS $(37.98 \pm 1.99 \%), 0.1 \mathrm{M} \mathrm{HCl}(43.75 \pm 8.81 \%)$ and PBS $7.4(61.53 \pm 2.31 \%)$ media, following the same order observed for capsules containing 12\% F127. The percentage of INS released from capsules containing 16\% F127 lyophilized product was also negatively affected by the presence of BS in the dissolution media. 
Collecting together, these results showed that the dissolution media significantly affected the release behavior of INS from capsules containing 12\% and 16\% F127 lyophilized products, and that the presence of BS in the media has promoted the slowest release of INS.

In a lyophilized product, it was expected that the 16\% F127 formulation could dissolve slower than the 12\% F127 formulation because the higher concentration of the polymer would generate smaller ice crystals during the freezing step, reducing the pores size and the diameter of network connections formed by the dry layer after water sublimation (ANDERSON et al., 2001; BOSS et al., 2004; MUDASSIR et al., 2019, YOU et al., 2019). When comparing the effect of F127 concentration on the percentage of INS released in the same medium, statistically significant difference was only observed in $0.1 \mathrm{M} \mathrm{HCl}$ medium $(P=0.0022)$. These result might indicate that the higher surface area created during the lyophilization process, when in contact with the release medium, favored the rapid rehydration of the capsules and the lyophilized product inside of them, overshadowing the effect of the concentration of the polymer, leading to a similar release profile of INS, except in acidic medium wherein INS is readily soluble, and the higher concentration of F127 has promoted the slowest release of INS (BOSS et al., 2004).

Table 1 - Mean micelle/vesicles size formed in different media after insulin release from gelatin capsules containing $12 \%$ and $16 \%$ F127 lyophilized products.

\begin{tabular}{|c|c|c|c|}
\hline $\begin{array}{c}\text { Lyophilized } \\
\text { product }\end{array}$ & $\begin{array}{c}\text { Dissolution } \\
\text { media }\end{array}$ & $\begin{array}{c}\text { Mean micelle } \\
\text { size }(\mathrm{nm})\end{array}$ & $\begin{array}{c}\text { Polydispersity } \\
\text { index }^{\mathrm{b}}\end{array}$ \\
\hline \multirow{4}{*}{$12 \%$ F127 } & $0.1 \mathrm{M} \mathrm{HCl}$ & $1151.77 \pm 146.76$ & $1,60 \pm 0.22$ \\
\hline & PBS 7.4 & $98.23 \pm 26.09$ & $1.16 \pm 0.36$ \\
\hline & $0.1 \% \mathrm{BS}$ & $63.93 \pm 3.20$ & $0,98 \pm 0.04$ \\
\hline & $1.0 \% \mathrm{BS}$ & $514.45 \pm 53.81$ & $1,09 \pm 0.10$ \\
\hline \multirow{4}{*}{$16 \%$ F127 } & $0.1 \mathrm{M} \mathrm{HCl}$ & $713.55 \pm 2.89$ & $1.38 \pm 0.11$ \\
\hline & PBS 7.4 & $38.90 \pm 1.57$ & $0.96 \pm 0.22$ \\
\hline & $0.1 \% \mathrm{BS}$ & $41.15 \pm 3.86$ & $0.96 \pm 0.07$ \\
\hline & $1.0 \% \mathrm{BS}$ & $252.00 \pm 94.46$ & $1.75 \pm 0.36$ \\
\hline
\end{tabular}

In Table 1 is presented the mean size of micelle/vesicle formed in the media after INS release from capsule containing 12\% and 16\% F127 lyophilized products. According to Table 1, the smallest mean micelle/vesicle size was observed in $0.1 \%$ BS medium. Additionally, it was observed that the mean micelle/vesicle size formed from capsules containing 12\% F127 lyophilized product in all media were bigger than capsules containing 16\% F127 lyophilized products, but both formulations followed the same ascending order of mean micelle/vesicle size of $0.1 \% \mathrm{BS}, \mathrm{PBS} 7.4,1.0 \% \mathrm{BS}$ and $0.1 \mathrm{M} \mathrm{HCl}$ medium. Interestingly, the data in table 1 also indicated that the increase in BS concentration in the dissolution medium increased the mean micelles/vesicle size over eight times from $12 \%$ F127 formulation and six times from 16\% F127 formulations. 
BS are organic surfactants present in the intestinal lumen responsible for the in vivo emulsification of fat material to assist in the absorption of fatty acids, monoglycerides, cholesterol and other lipids (DAVIES et al., 2002). This ability makes BS capable of improving the bioavailability of hydrophilic drugs by increase its rate of solubilization/dissolution on the intestinal tract, at the same time it promotes the emulsification of fat material (AHMAD et al., 2017).

As amphiphilic molecules with hydrophobic and hydrophilic regions, bile salts accommodate their selves at the lipid/water interface (DAVIES et al., 2002). It is suggested that the amphiphilic behavior of BS could facilitate their incorporation into the dried micelles of F127 during rehydration of capsules containing the lyophilized products. Its incorporation into the micellar structure of F127 could increase the micelles size, reducing the number and the dimension of the water channels and, consequently, obstructing the INS release.

Furthermore, Torcello-Gómez et al. (2013) have demonstrated that BS are able to form mixed micelles in presence of other amphiphilic molecules like F127. The formation of mixed micelles in presence of BS was shown to affect the micellization ability of F127. Therefore, in $1.0 \%$ BS medium, the concentration of BS could be higher enough to form micelles and to solubilize lipids and hydrophobic substances (SHARMA et al., 2005), affecting the erosion and dissolution of the F127 hydrogel matrix in comparison to $0.1 \% \mathrm{BS}$ medium and, consequently, accelerating the release of INS from the formulations (see Fig. 1 and 2).

The mean micelle/vesicles size is an inherent factor for permeation in biological membranes (MÄLKIÄ et al., 2004). The results demonstrated that the presence of BS in the release media leaded to the formation of small micelle/vesicles. The formation of small mixed micelles on the intestinal tract can be a key factor to improve the absorption of INS administered by oral route, since BS can induce changes that increases membrane permeability to various substances (MIKOV et al., 2006), as well as to affect the transfer of hydrophilic drugs dissolved in the media through the absorption barrier due to interactions among BS and the mucous layer covering the cells membrane (SILVA et al., 2003; MIKOV et al., 2006; CHUN et al., 2012).

Morishita et al. (2004) observed that smaller was the INS microparticles, better was its adhesion to the intestine mucosa and its absorption into the small intestine, increasing the INS bioavailability and its hypoglycemic effect. The authors suggested that this phenomenon was due to the increased contact area and protection against enzymatic degradation promoted by the smaller microparticles (MORISHITA et al., 2004).

\section{CONCLUSION}

The results described here demonstrated that capsules containing the $12 \%$ and $16 \% \mathrm{~F} 127$ lyophilized products could be useful formulations for oral administration of INS, if considering that 
in vivo, the BS present on the intestine lumen could help on the emulsification of INS and OA, leading to the formation of small mixed vesicles/micelles, assisting on INS permeation/absorption through the intestinal mucosa.

\section{ACKNOWLEDGEMENTS}

This work was supported by the CNPq (National Council for Scientific and Technological Development), processes number 479811/2009-1 and 553525/2010-7, and by FAPEMIG (Fundação de Amparo a Pesquisa do Estado de Minas Gerais), process number PPM 00282-11.

\section{REFERENCES}

AHMAD, J. et al. Bile Salt Stabilized Vesicles (Bilosomes): A Novel Nano-Pharmaceutical Design for Oral Delivery of Proteins and Peptides. Current Pharmaceutical Design, v. 23, p. 1575-1588, 2017.

ANDERSON, B. C. et al. Understanding Drug Release from Poly(ethylene oxide)- $b$-poly(propylene oxide)- $b$-poly(ethylene oxide) Gels, Journal Controlled Release, v. 70, n. 1-2, p. 157-167, 2001.

AYRES, M. et al. BioEstat: Aplicações Estatísticas nas Áreas das Ciências Biomédicas. Belém, PA, Brasil: Ong Mamiraua, 2007. 4. ed.

BARICHELLO, J. M. et al. Enhanced Rectal Absorption of Insulin-Loaded Pluronic F127 Gels Containing Unsaturated Fatty Acids. International Journal of Pharmaceutics, v. 183, n. 2 , p. 125-132, 1999a.

BARICHELLO, J. M. et al. Absorption of Insulin from Pluronic F127 Gels Following Subcutaneous Administration in Rats. International Journal of Pharmaceutics, v. 184, n. 2, p. 189-198, 1999 b.

BARICHELLO, J. M. et al. Encapsulation of Hidrophilic and Lipophilic Drugs in PLGA Nanoparticles by the Nanoprecipitation Method. Drug Development and Industrial Pharmacy, v. 25, n. 4, p. 471-476, 1999c.

BOSS, E. A. et al. Freeze-Drying Process: Real Time Model and Optimization. Chemical Engineering and Processing: Process Intensification, v. 43, n. 12, p. 1475-85, 2004. 
CHOONARA, B. F. et al. A review of advanced oral drug delivery technologies facilitating the protection and absorption of protein and peptide molecules. Biotechnology Advances, v. 32, n. 7, p. 1269-1282, 2014.

CHUN, I. K. et al. Effects of Bile Salts on Gastrointestinal Absorption of Pravastatin. Journal of Pharmaceutical Sciences, v. 101, n. 7, p. 2281-7, 2012.

DAVIES, A. et al. Funções Endócrinas do Trato Gastrointestinal e do Pâncreas. Fisiologia Humana. Porto Alegre, RS, Brazil: ARTEMED, 2002. p. 451-456.

DUMORTIER, G. et al. A Review of Poloxamer 407 Pharmaceutical and Pharmacological Characteristics. Pharmaceutical Research, v. 23, n. 12, p. 2709-2728, 2006.

FONTE, P. et al. Oral Insulin Delivery: How Far Are We? Journal of Diabetes Science and Technology, v. 7, n. 2 , p. $520-531,2013$

MÄLKIÄ, A. et al. Drug Permeation in Biomembranes: in Vitro and in Silico Prediction and Influence of Physicochemical Properties. European Journal of Pharmaceutical Sciences, v. 23, n. 1, p. 13-47, 2004.

MIKOV, M. et al. Pharmacology of Bile Acids and Their Derivatives: Absorption Promoters and Therapeutic Agents. European Journal of Drug Metabolism and Pharmacokinetics, v. 31, n. 3, p. 237-251, 2006.

MORISHITA, M. et al. The Dose-Related Hypoglycemic Effects of Insulin Emulsions Incorporating Highly Purified EPA and DHA. International Journal of Pharmaceutics, v. 201, n. 2, p. 175-185, 2000.

MORISHITA, M. et al. Pluronic ${ }^{\circledR}$ F127 Gels Incorporating Highly Purified Unsaturated Fatty Acids for Buccal Delivery of Insulin. International Journal of Pharmaceutics, v. 212, n. 2, p. 289-293, 2001.

MORISHITA, M. et al. Mucosal Insulin Delivery Systems Based on Complexation Polymer Hydrogels: Effect of Particle Size on Insulin Enteral Absorption. Journal of Controlled Release, v. 97, n. 1, p. 115-24, 2004. 
MUDASSIR J et al. Self-assembled insulin and nanogels polyelectrolyte complex (Ins/NGs-PEC) for oral insulin delivery: characterization, lyophilization and in-vivo evaluation. International Journal of Nanomedicine, v. 14, 4895-4909, 2019.

OBACH, E. S. et al. Novas Estratégias Farmacotécnicas para a Administração de Insulina por Vias Não Parenterais. Pharmacia Brasileira, v. 2, n. 16, p. 54-60, 1999.

REY, L. et al. Freeze-Drying/Lyophilization of Pharmaceutical and Biological Products. New York, USA: Marcel Dekker, 1999. 487p.

SHARMA P. et al. Absorption enhancement, mechanistic and toxicity studies of medium chain fatty acids, cyclodextrins and bile salts as peroral absorption enhancers. Il Farmaco, v. 60, n. 11-12, p. 884-893, 2005.

SIEKMEIER, R. et al. Inhaled Insulin Does it Become a Reality? Journal of Physiology and Pharmacology, v. 59, n. 6, p. 81-113, 2008.

SILVA, C. et al. Administração Oral de Peptídeos e Proteínas: III. Aplicação à Insulina. Revista Brasileira de Ciências Farmacêuticas, v. 39, n. 1, p. 21-40, 2003.

TORCELLO-GÓMEZ, A. et al. Interactions Between Pluronics (F127 and F68) and Bile Salts (NaTDC) in the Aqueous Phase and the Interface of Oil-in-Water Emulsions. Langmuir: the ACS Journal of Surfaces and Colloids, v. 29, n. 8, p. 2520-9, 2013.

YOU X. et al. Stabilization of Deformable Nanovesicles Based on Insulin-Phospholipid Complex by Freeze-Drying. Pharmaceutics, v. 11, 539-559, 2019. 